\title{
PELATIHAN TARI PERSEMBAHAN BAGI GURU SDN 47 KOTA BENGKULU
}

\author{
Dwi Anggraini, Hasnawati, Neza Agusdianita \\ Universitas Bengkulu \\ dwianggraini@unib.ac.id, hasnaapri121@gmail.com \\ nezaagusdianita@unib.ac.id
}

\begin{abstract}
ABSTRAK
Pelatihan dan pendampingan tari Persembahan Propinsi Bengkulu dilatarbelakangi oleh kebutuhan kurikulum akan praktik pembelajaran seni tari di jenjang sekolah dasar dan melestarikan tari tardisional Bengkulu. Kegiatan ini bertujuan untuk meningkatkan pengetahuan dan keterampilan guru dalam mempraktikkan tari Persembahan Propinsi Bengkulu. Metode yang digunakan yaitu pelatihan dan pendampingan. Teknik pengumpulan data adalah observasi untuk mendeskripsi proses pelatihan dan praktik tari Persembahan dan tes untuk mengukur pengetahuan guru (pretest dan postest). Hasil kegiatan ini guru dapat mengikuti proses pelatihan dan praktik dengan baik, serta hasil pretest dan postest menunjukkan peningkatan yaitu hanya $36,36 \%$ guru yang mampu mendapatkan nilai $\geq 60$ saat pretest, meningkat menjadi $81,82 \%$ guru mampu mendapatkan nilai $\geq 60$ saat postest. Simpulan dari kegiatan ini adalah kegiatan ini dapat meningkatkan pengetahuan guru sasaran baik dari segi teoretis maupun praktik.
\end{abstract}

Kata Kunci: Tari Persembahan, Bengkulu, Pengetahuan, Keterampilan. 


\section{PENDAHULUAN}

Pembelajaran seni tari merupakan mata pelajaran wajib yang harus diimplementasikan oleh guru di SD. Namun Permasalahan yang ada pada sekolah ini yaitu pada kompetensi guru kelas yang tidak menguasai pengetahuan seni, khususnya tari baik secara teoretis maupun praktis. Pembelajaran Seni Budaya dan Keterampilan (SBK) hanya diisi oleh kegiatan menyanyi atau menggambar bebas. Jika dilihat pada kurikulum KTSP, pembelajaran SBK ditekankan pada empat bidang, yaitu Seni Tari, Seni Rupa, Seni Musik, dan Keterampilan. Dari keempat tuntutan kurikulum tersebut yang jarang diterapkan adalah bidang seni tari.

Pembelajaran seni tari dalam kurikulum mencakup apresiasi terhadap karya tari daerah setempat, nusantara dan mancanegara. Tidak diajarkannya seni tari pada pembelajaran SBK di sekolah ini dikarenakan tidak ada guru khusus bidang tari yang akan mengajarkan seni tari. Oleh sebab itu, hal ini menjadi tanggung jawab guru kelas yang harus menguasai semua bidang ilmu termasuk seni tari. Pembelajaran seni tari di SD tidak menjadikan siswa sebagai seniman tari. Melalui pembelajaran seni siswa mampu mengekspresikan diri dan mengapresiasi seni tari baik yang ada di daerahnya maupun tari nusantara lainnya. Guru kelas tidak harus mampu mengajarkan dan mempraktikkan semua jenis tarian yang ada di daerah Bengkulu maupun tari nusantara dan mancanegara. Namun setidaknya guru mampu mengajarkan salah satu dari semua tari yang ada agar tujuan kurikulum dapat tercapai. Seperti misalnya untuk dapat memenuhi Standar Kompetensi Mengapresiasi Karya Seni Tari Daerah Setempat, maka guru dapat mengajarkan Tari Persembahan Bengkulu, yang mana tari ini menjadi ciri khas untuk ditampilkan dalam acara-acara resmi untuk menyambut tamu kehormatan di masyarakat dan juga sekolah. Dengan adanya guru kelas yang mampu mengajarkan tari Persembahan, maka manfaat yang didapatkan yaitu siswa dapat mengenal gerak, busana, alat musik dan properti Cerano serta makna yang terkandung di dalam tari Persembahan dan dapat mengapresiasi tari tersebut dengan menarikannya pada acara-acara resmi di sekolah tanpa harus membayar pelatih dari luar sekolah.

Selain hal tersebut, dengan diajarkan tari Persembahan di sekolah-sekolah menjadikan eksistensi tari Persembahan dapat terjaga dengan baik dan diharapkan dapat menimbulan rasa memiliki tari tersebut di dalam diri siswa, dengan demikian proses pewarisan dapat berjalan dengan sinergis. Hal ini sejalan dengan pendapat Syafrayuda (2015: 201-202) yang mengatakan bahwa tari Payung hadir di lingkungan terpelajar (kota dan nagari) dan merupakan kebanggaan 
bagi masyarakat sehingga eksistensi tari $\mathrm{Pa}$ yung tetap terjaga. Di lain sisi, tari payung mengandung nilai sosial, begitupun dengan tari Persembahan yang mana tari ini memerlukan interaksi antara penari dan tamu saat mengambil sirih sebagai tanda kehormatan kepada tamu.

Tari Persembahan ditarikan oleh penari perempuan yang berjumlah ganjil, tanpa dibatasi jumlah penarinya. Biasanya, masyarakat menggunakan 5-7 penari saja. Pada masyarakat Bengkulu, gerak tari Persembahan berasal dari gerak-gerak tari yang mewakili 4 wilayah di Provinsi Bengkulu, yaitu Kotamadya, Bengkulu, Utara, Bengkulu Selatan, dan Rejang Lebong. Wilayah tersebut merupakan wilayah Provinsi Bengkulu sebelum terjadi pemekaran, yang mana sekarang sudah menjadi 10 wilayah, yaitu Kotamadya, Bengkulu Tengah, Bengkulu Selatan, Seluma, Kaur, Bengkulu Utara, Muko-muko, Rejang Lebong, Kepahyang dan Lebong. Gerak tari tradisi yang berasal dari keempat wilayah Provinsi Bengkulu tersebut diambil dari gerak tari adat Rejang yaitu jangkerna, gerak tari adat Bengkulu Utara yaitu Menjong Gedang yang sekarang menjadi Gandai dari Kabupaten Muko-muko, gerak dari tari adat Rejang Lebong yaitu Sembah Kejei, dan gerak dari tari adat Bengkulu Selatan yaitu gerak tari Andun serta yang terakhir kotamadya gerak sembah (Meilani, 2016). Kostum yang digu- nakan dalam menampilkan tari persembahan ini yaitu baju kurung beludru dengan tabur emas dengan motif tabur "B", kain songket, dan tadah peluh (teratai) dengan bandul kunci dan gembok. Adapun aksesoris yang digunakan yaitu sunting kembang intan lima buah, sunting burung-burung sepasang, kalung, anting-anting dan gelang masing-masing satu buah di tangan kanan dan kiri serta menggunakan sanggul sikek.

Instrumen musik yang digunakan untuk mengiringi tari Persembahan ini adalah serunai dan dua gendang panjang, serta kelintang. Lagu yang dimainkan oleh serunai adalah lagu belarak. Serunai dimainkan saat pembukaan tari yang di awali oleh Silat Pedang dan penutupan tari saat penari memberikan sirih kepada tamu. Dua gendang panjang memiliki perannya masing-masing. Gendang yang pertama berperan sebagai gendang melalu, yaitu memainkan motif atau pukulan gendang yang konstan, tidak berubah dari awal hingga akhir. Gendang yang kedua berperan sebagai gendang betingkah, yaitu memainkan motif yang meningkahi gendang pertama atau pukulannya mengisi motif gendang melalu.Kolintang merupakan alat perkusi melodis yang berperan sebagai pemberi irama lagu pada musik tari persembahan (Anggraini, 2016: 78).

Tari Persembahan menggunakan properti cerano. Cerano ini dipercayai sebagai 
penolak bala, karena menurut kepercayaan masyarakat Bengkulu isi cerano memiliki makna yang berkaitan dengan adat maupun agama. Isi cerano jika dibahasakan akan menjadi adat besandi Syarak, Syarak besandi Kitabullah, yang artinya adat berpegang kepada agama dan agama mengacu kepada kitab suci Al Qur'an. Adapun isi dari Cerano tersebut adalah sirih 5 lepit (helai), gambir, pinang, tembakau, kapur, serta dilengkapi rokok 7 batang dan lilin sebatang. Daun sirih 5 lembar merupakan penggambaran dari 5 rukun Islam. Pinang digores 8 pada bagian atas merupakan penggambaran dari hurufhuruf hijaiyah Allahuakbar yang berjumlah 8 huruf. Selain Pinang, yang digores 8 pada bagian atasnya adalah gambir. Penjumlahan gores yang ada pada pinang dan gambir yang berjumlah enam belas merupakan penggambaran kalimat Syahadat. Adapun rokok berjumlah 7 batang merupakan penggambaran dari surat Al Fatihah yang berjumlah 7 ayat. Rokok tersebut dirakit 3 banjar yang berarti Tasdid (diniatkan di dalam hati), ikrar (diucapkan dengan mulut), dan perbuatan (dikerjakan oleh anggota tubuh). Di dalam adat atau lembago, dikenal dengan istilah sirih 5 subang (4 dimakan dan 1 dibuang). Maksudnya adalah dari 5 inti isi Cerano (sirih, gambir, pinang, kapur sirih dan tembakau) yang hanya boleh dimakan adalah daun sirih, gambir, pinang dan kapur, sedangkan tembakau tidak dimakan. Jika dihubungkan dengan ajaran Islam, hal ini merupakan penggambaran dari Mashab Islam atau Imam, yaitu Imam Syafi'I, Imam Hambali, Imam Hanafi dan Imam Maliki, serta penggambaran dari Sahabat Nabi Muhammad SAW, yaitu Abu Bakar Shidiq, Umar bin Khatab, Usman bin Hafan, dan Ali bin Abi Thalib (Anggraini, 2012:80-81).

Berdasarkan pemaparan di atas, dapat dilihat bahwa makna yang terkandung dalam tari Persembahan sangat baik, apalagi dapat ditransfer kepada generasi muda dan dapat mengaplikasikannya dalam kehidupan sehari-hari. Namun hal ini belum pernah disampaiakna dalam proses pembelajaran pendidikan formal. Permasalahan seperti yang dipaparkan tersebut juga terjadi di SDN 47 Kota Bengkulu. Maka SD ini dijadikan mitra pada kegiatan Pengabdian Pada Masyarakat (PPM). Sekolah ini berada di Pesisir Pantai Panjang Bengkulu di kecamatan Teluk Segara Kota Bengkulu. Sekolah ini termasuk pada sekolah yang berprestasi cukup, artinya prestasi yang diraih masih sedikit dan sekolah ini jarang sekali dijadikan mitra PPL.

Berdasarkan permasalahan di atas, maka dirasa sangat penting untuk diadakannya pelatihan dan pendampingan Tari Persembahan dalam rangka meningkatkan pengetahuan dan keterampilan Guru pada Pembelajaran SBK di SDN 47 Kota Bengkulu, mengingat manfaat yang didapatkan 
melalui pelatihan ini sangat besar.

\section{METODE PENGABDIAN}

Kegiatan ini dilaksanakan dua tahap. Tahap pertama yaitu pelatihan dan praktik yang dilaksanakan pada tanggal 20 September 2017 dan pendampingan mengajar di kelas dengan menerapkan tari Persembahan Propinsi Bengkulu dilaksanakan pada tanggal 3 September 017. Adapun sasaran kegiatan ini adalah guru-guru di SDN 47 Kota Bengkulu.

Metode yang digunakan pada kegiatan PPM ini adalah pelatihan dan pendampingan. Pelatihan dilakukan untuk menambah pengetahuan dan wawasan guru tentang pengetahuan Tari Persembahan yang mencakup gerak, busana, alat musik dan propertI yang digunakan, serta melatih keterampilan guru dalam praktik tari Persembahan. Setelah guru sasaran menguasai pengetahuan dan keterampilan tersebut, selanjutnya mereka diminta untuk menerapkan keterampilan yang telah dimiliki pada proses pembelajaran sebenarnya di kelas. Guru sasaran diminta untuk melaksanakan pembelajaran SBK bidang Seni Tari dengan menerapkan Tari Persembahan. Tim PPM melakukan pendamping secara terus menerus untuk mengarahkan, membimbing, dan membantu guru sasaran dalam pendalaman materi Tari Persembahan baik dari segi teoretis maupun praktis.
Teknik pengumpulan data yang digunakan adalah observasi dan tes. Observasi digunakan untuk mengamati proses kegiatan pelatihan dan juga praktik tari Persembahan Propinsi Bengkulu. Sedangkan tes untuk mengukur tingkat pengetahuan guru yang dilakukan sebanyak dua tahap, yaitu sebelum diberikan pelatihan (pretest) dan setelah pelatihan diberikan (postest).

\section{HASIL DAN PEMBAHASAN}

\section{A. Hasil}

\section{Deskripsi Pelatihan Tari Persembahan}

\section{Propinsi Bengkulu}

Pelatihan diikuti oleh 11 orang guru sasaran. Adapun tahapan penyampaian materi mencakup: fungsi tari Persembahan Propinsi Bengkulu dalam masyarakat Melayu, kostum, alat/ instrumen musik dan properti cerano. Sesi ini memberikan pengetahuan yang baru kepada peserta tentang seluk beluk tari Persembahan Propinsi Bengkulu. Materi tersebut dikemas dalam modul Tari Persembahan agar peserta dapat mengulang kembali materi tesebut dilain waktu.

Selain teori, tim PPM juga memberikan praktik tari Persembahan Propinsi Bengkulu. Semua peserta antusias mengikuti pelatihan. Dikarenakan di sekolah tersebut belum pernah ada pelatihan-pelatihan terutama di bidang seni tari, khususnya tari Persembahan yang sangat mereka butuhkan 
dalam praktik di sekolah.

Berdasarkan observasi yang dilakukan, praktik dilakukan tahap demi tahap, dimulai dari gerakan pertama yaitu salam pembuka, hingga gerak terakhir yaitu salam penutup. Dari adpek wiraga, didapatkan hasil bahwa seluruh guru dapat mengikuti gerak yang diberikan oleh tim PPM. Gerak yang diberikan dapat dengan mudah diterima dan ditiru oleh guru. Gerak tersebut hanya dicontohkan 3 kali dan bisa ditiru oleh guru. Namun demikian, gerak tersebut belum mengikuti disiplin gerak tari Persembahan yang sebenarnya.

Gerak pertama yaitu sembah. Pada gerak sembah masih ada guru yang tidak membuka ketiak. Untuk ragam gerak yang kedua, sama halnya dengan gerak sembah, kebanyakan dari guru tidak membuka ketiaknya ketika kedua tangan digerakkan ke belakang dan digerakkan kembai ke depan dada. Ragam gerak ketiga yaitu gerak dari tari Gandai. Pada ragam gerak ini, saat posisi kaki kiri diletakkan ke depan, posisi kaki yang benra adalah memposisikan tumit untuk menampak. Namun guru masih ada yang menggunakan ujung jari untuk menampak. Saat gerak sembah kejei, semua guru melakukan gerak dengan benar. Gerak selanjunya yaitu gerak tari Andun. Guru dapat dengan mudah mengikuti gerakkan ini karena geraknya sederhana. Begitupun dengan gerak kejei dan gerak sembah penutup.

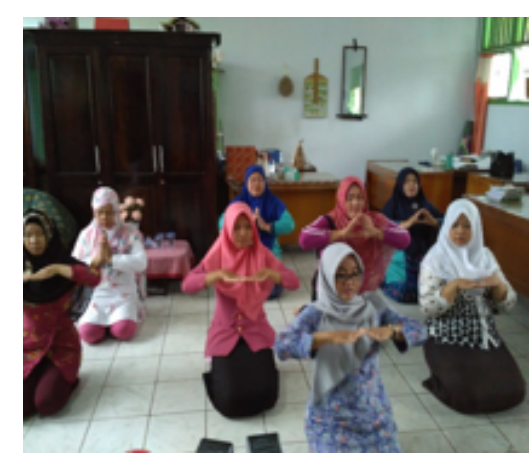

Foto 1. Gerak Sembah Akhir

Pada aspek wirasa, guru sebagian bisa menghayati gerak. Hal ini dikarenakan belum dapat menghapal gerak dengan baik. Sehingga setiap pergantian gerak guru masih harus diberitahu terlebih dahulu. Aspek wirasa ini berhubungan dengan gerak wirama. Guru belum mampu mengikuti atau merasakan perbedaan-perbedaan bunyi musik tari ketika terjadi perpindahan gerak.

Dari 11 orang guru yang menjadi sasaran di SD 47 Kota Bengkulu, ada 3 orang guru yang sudah mampu mempraktikkan tari Persembahan Propinsi Bengkulu tanpa dicontohkan oleh tim PPM. Sehingga ketiga guru ini dijadikan model bagi sekolah tersebut untuk melatih tari Persembahan.

\section{Deskripsi Praktik Pembelajaran Tari}

\section{Persembahan}

Praktik pembelajaran dilakukan di kelas V SDN 47 Kota Bengkulu pada tanggal 23 September 2017. Adapun hasil pengama- 
tan yang telah dilakukan adalah sebagai berikut.

\section{a. Kegiatan Pendahuluan}

Awal pembelajaran guru mengajak siswa berdo'a dan kemudian mengecek kehadiran siswa. Lalu guru memberikan apersepsi dan mengaitkannya dengan pembelajaran yang terdahulu serta menyampaikan tujuan dan materi pembelajaran yang akan dilakukan.

\section{b. Kegiatan Inti}

Pada kegiatan inti, guru menampilkan gambar-gambar yang terkait dengan tari persembahan dan kemudian melakukan tanya jawab. Guru memberikan menjelaskan tentang segala sesuatu yang terkait dengan tari Perembahan seperti, gerak, kostum, alat musik, dan properti yang digunakan dalam tari tersebut. Lalu guru menayangkan video tari Persembahan sambil bertanya jawab dengan siswa. Setelah itu siswa dibagi menjadi beberapa kelompok secara heterogen.

Kemudian guru memberikan LDS dan menjelaskan langkah-langkah mengerjakan LDS tersebut. Siswa dengan bimbigan guru mengerjakan LDS yang berkaitan dengan tari Persembahan dan mempresentasikannya di depan kelas.

Setelah melakukan diskusi dan presentasi, guru memberikan praktik tari Persembahan kepada siswa. Guru memberikan gerakkan secara bertahap seperti yang dilakukan oleh tim PPM pada saat pelatihan. Sehingga siswa dengan mudah dapat menirukan gerak. Untuk siswa laki-laki, guru memberikan gerak tari Silat Pedang. Diakhir kegiatan init, guru memberikan bintang kepada kelompok yang aktif di dalam diskusi dan praktik tari Persembahan.

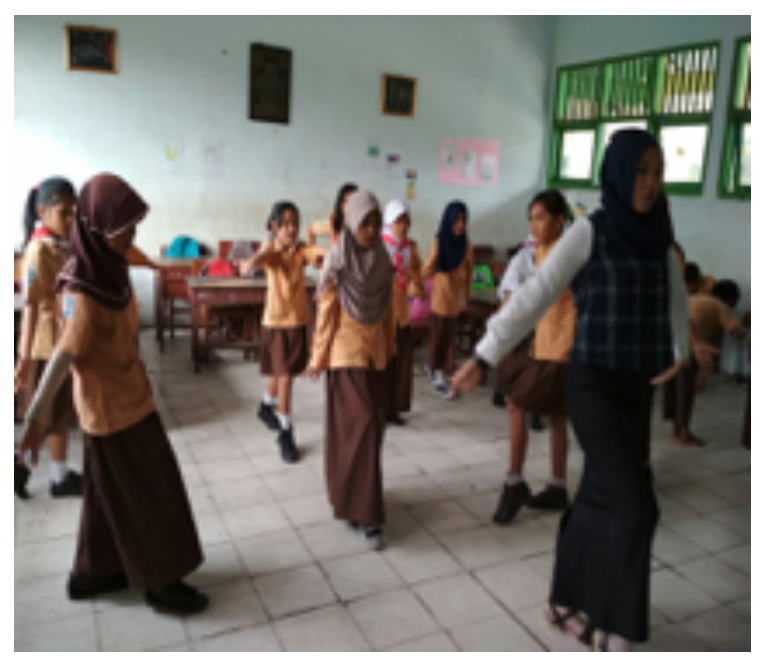

Foto 2. Ragam Gerak 2

\section{c. Kegiatan Penutup}

Guru dan siswa menarik kesimpulan dari pembelajaran yang telah dilakukan. Kemudian guru memberikan evaluasi dan menutup pembelajaran dengan berdo’a.

\section{Tes}

Untuk mengukur pengetahuan guru sasaran tentang tari Persembahan, dilakukan tes sebanyak dua tahap. Tahap petama tes dilakukan sebelum pelatihan di mulai (Pretest) dan tahap kedua dilakukan setelah pelatihan selesai dilaksanakan (Postest).Berdasarkan 
pengolahan data, hasil tes dapat dirincikan pada tabel berikut ini.

Tabel 1. Persentase Hasil Pretest Guru Sasaran

\begin{tabular}{cccc}
\hline No & Kriteria & $\begin{array}{c}\text { Jumlah } \\
\text { Guru }\end{array}$ & Persentase \\
\hline 1 & $\geq 60$ & 4 & $36,36 \%$ \\
\hline 2 & $\leq 59$ & 7 & $63,64 \%$
\end{tabular}

Berdasarkan pengolahan data prersentase hasil pretest tersebut, dapat terlihat bahwa sebagian besar guru sasaran belum memahami secara rinci tentang tari Persembahan Propinsi Bengkulu. Hal ini terlihat bahwa lebih dari 50\% guru sasaran mendapatkan nilai $\leq 59$. Setelah mengikuti pelatihan dan mendapat penjelasan materi serta praktik tari Persembahan, guru diberikan postest. Adapun hasil postest dapat dilihat pada tabel berikut ini.

Tabel 2. Persentase Hasil Postest Guru Sasaran

\begin{tabular}{cccc}
\hline No & Kriteria & $\begin{array}{c}\text { Jumlah } \\
\text { Guru }\end{array}$ & Persentase \\
& \multicolumn{3}{c}{ Gur } \\
\hline 1 & $\geq 60$ & 9 & $81,82 \%$ \\
& & & $18,18 \%$
\end{tabular}

Berdasarkan tabel di atas, dapat dilihat bahwa sebagian besar guru (lebih dari $50 \%$ ) mencapai nilai $\geq 60$, artinya guru sasaran sudah memahami tentang tari persembahan. Selama melakukan pengabdian, terdapat beberapa kendala yaitu dikarenakan kondisi cuaca pada saat pelatihan hujan deras, maka pelatihan yang pada mulanya direncanakan mulai pukul 08.00 wib, diundur menjadi pukul 09.00 wib hingga selesai. Selain itu, pada saat pelatihan guru keluar masuk ruangan, dikarenakan harus masuk kelas dan ada beberapa siswa yang bolak-balik memanggil guru. Terkait dengan pemberian materi pelatihan praktik itu sendiri tidak terdapat hambatan yang menggangu lancarnya pelatihan ini.

\section{B. Pembahasan}

Berdasarkan hasil pengolahan data, dapat dilihat bahwa pelatihan tari Persembahan Propinsi Bengkulu ini dapat meningkatkan pengetahuan guru tentang tari Persembahan baik teoretis maupun praktik. Hal ini terlihat dari hasil tes yang dilakukan, bahwa pada saat pretest $63,64 \%$ guru belum menguasi pengetahuan tentang tari persembahan. Setelah diberikan pelatihan yaitu dengan memberikan materi tentang tari Persembahan secara rinci, baik itu tentang gerak, kostum, alat musik dan properti, pengetahuan guru meningkat dengan dibuktikan oleh meningkatnya jumlah guru yang mendapatkan nilai 
$\geq 60$ yaitu sebanyak 9 orang $(81,82 \%)$. Dengan demikian dapat dilihat peningkatan pengatahuan guru tentang tari Persembahan.

Dengan meningkatnya pengetahuan guru tersebut, tentunya dapat membantu guru dalam menerapkannya di dalam pembelajaran. Hal ini akan dapat mendukung tercapainya program yang ada pada kurikulum sehingga tujuan pembelajaran tercapai dengan baik. Seperti yang diungkapkan dalam BSNP (2006) bahwa tujuan mata pelajaranSBK adalah agar peserta didik memiliki kemampuan sebagai berikut.

1. Memahami konsep dan pentingnya seni budaya dan keterampilan

2. Menampilkan sikap apresiasi terhadap seni budaya dan keterampilan

3. Menampilkan kreativitas melalui seni budaya dan keterampilan

4. Menampilkan peran serta dalam seni budaya dan keterampilan dalam tingkat lokal, regional, maupun global.

Selain pengetahuan, keterampilan guru dalam mempraktikkan tari Persembahan juga meningkat. Dari aspek wiraga, awal praktik guru terlihat kaku dan belum mengetahui gerak tari persembahan dari awal hingga akhir. Guru juga melakukan gerakan tanpa memperhatikan keindahan ruang yang harus diciptakan oleh anggota tubuh melalui gerakan. Setelah dilakukan latihan dan mengulang-ulang gerak, guru dapat mengikuti gerak tari Persembahan walaupun belum sempurna dan mulai untuk menghafal gerakan bagian per bagian dari motif gerak yang diberikan. Selain gerak, sensitivitas guru terhadap musik tari persembahan juga meningkat. Awalnya bingung membedakan musik bagian per bagian, setelah dilakukan latihan berulang kali, guru sudah mulai peka terhadap perbedaan musik dan mulai merasakan dan berekspresi sesuai dengan tema atau karakter tari Persembahan yaitu anggun.

Seperti yang diungkapkan oleh Abduracham dan Rusliana dalam Mulyani (2006: 52) bahwa nilai-nilai keindahan suatu tarian terletak pada empat unsur, pertama yaitu wiraga yang mana unsur ini terkait dengan hafalan, teknik dan ruang, kedua wirasa yang menyangkut penjiwaan atau kemampuan penari dalam mengungkapkan rasa emosi sesuai dengan isi atau tema atau karakter tarian, ketiga yaitu wirama yang terkait dengan ketajaman rasa atau kepekaan penari terhadap irama yang menyatu dalam setiap ungkapan gerak, dan keempat yaitu harmoni yang menekankan pada interelasi yang menyeluruh dari tarian yang dibawakan oleh penari (keselarasan kemampuan wiraga, wirasa, dan wirama).

\section{SIMPULAN}

Berdasarkan kegiatan yang telah dilakukan, maka dapat disimpulkan sebagai 
berikut:

1. Pengetahuan guru SDN 47 Kota Bengkulu tentang tari Persembahan Propinsi Bengkulu meingkat.

2. Keterampilan guru SDN 47 Kota Bengkulu dalam mempraktikkan tari Persembahan Propinsi Bengkulu Meningkat.

Adapun saran yang dapat disampaikan yaitu: 1. Koordinasi antaratim PPM dan pihak sekolah harus dilakukan dengan baik, sehingga pihak sekolah dapat mengkoordinir dengan baik guru-guru yang terlibat dalam keigatan dan juga dapat mengatur jadwal yang tepat sehingga tidak menggangu proses pembelajaran karena kegiatan ini melibatkan seluruh guru.

2. Jika kegiatan dijadwalkan pada jam mengajar, sebaiknya yang dijadikan sasaran tidak semua guru, melainkan beberapa orang guru saja dan melibatkan beberapa siswa yang dipilih dari masing-masing kelas pada setiap tingkatan.

\section{DAFTAR PUSTAKA}

Anggraini, Dwi. (2012). Pengembangan Multimedia Interaktif dengan Meng gunakan Model ADDIE untuk Pembe lajaran Seni Tari pada Siswa Sekolah Dasar. Tesis Magister Program Studi Pendidikan Seni UPI Bandung: tidak diterbitkan

Anggraini, Dwi. (2016). Pengembangan Multimedia Interaktif Silat Pedang Metode ADDIE untuk Pemb elajaran Seni Tari pada Siswa Sekolah Dasar. Jurnal PGSD FKIP Universitas Bengkulu. Volume 8 Nomor 3, Mei 2016.

Meilani, Melli. (2016).Studi Deskriptif Sikap Disiplin Dalam Gerak Tari Kreasi Persembahan Propinsi Bengkulu Pada Kegiatan Ekstrakurikuler Siswa SDIT Iqra' 2 Kota Bengkulu.

Mulyani, Novi. (2006). Pendidikan Seni Tari Anak Usia Dini. Gava Media: Yogya karta.

Kementrian Pendidikan dan Kebudayaan. (2005). Peraturan Pemerintah RI Nomor 19 Tahun 2005 tentang Badan Standar Nasional Pendidikan. Ke mendikbud: Jakarta.

Syafrayuda, Dian Rosari (2015). Eksistensi Tari Payung sebagai Tari Melayu Minangkau di Sumatera Barat. Jurnal Ekspresi Seni Vol 17 No 2 Hal 165323 Padangpanjang November 2015. 